\title{
IN-VITRO EVALUATION OF REMINERALIZATION EFFICIENCY OF CHICKEN EGGSHELL SLURRY ON ERODED DECIDUOUS ENAMEL
}

\author{
Gehan A. Elolimy*
}

\begin{abstract}
Objectives: The present study evaluated the re-mineralizing efficiency of CESP on experimentally eroded deciduous tooth enamel by Claritin syrup.

Materials and Methods: 20 extracted deciduous teeth had been selected and stored in normal saline. Each tooth was cut in a labiolingual direction into 2 halves, one half used as a control and the other used as study. Demineralization of all specimens were done by twice daily immersion in Claritin syrup for $1 / 2$ an hour for 12 days to form enamel erosion. Remineralization of the study group was done by using CESP slurry twice daily application for $3 \mathrm{~min}$. for 10 days. Surface roughness of the specimens was measured by surface profile gauge and microhardness evaluation was done using Vickers tester. Resulted data were tabulated and ana1yzed statistically by t-test with $5 \%$ significance 1 evel
\end{abstract}

Results: There was statistically significant increase in roughness values after erosion with Claritin syrup $(\mathrm{P}<0.001)$. however, it was significantly decreased after remineralization $(P=0.01)$. There was statistically significant decreased mean value of microhardness after erosion with Claritin syrup $(\mathrm{P}<0.001)$. however, it was significantly increased after remineralization $(P=0.01)$.

Conclusion: CESP slurry is a valuable topical treatment in deciduous teeth erosion since it decreased the roughness and increased the microhardness of the enamel surface in-vitro

KEY WORDS: Dental erosion, CESP, surface roughness, Vickers microhardness.

\section{INTRODUCTION}

Dental erosion is an acidic wearing of hard tooth tissue by chemical action of acidic dissolution that not caused by bacteria and isn't clearly related to mechanical action. ${ }^{(1,2)}$
Erosion of dental enamel may be happened by continuous application of acidic medium either from internal or external sources ${ }^{(3)}$. From the most commonly included intrinsic sources are frequent vomiting, re-gurgitation or gastro-esophageal reflex ${ }^{(4)}$. With respect to the external sources of

\footnotetext{
* Lecturer of Dental Biomaterials, Dental Biomaterials Departmeant, Faculty of Dentistry, Tanta University, Egypt.
} 
acidity, it was discovered that it likely could be because of the extreme confirmations of acidic liquids for example: carbonate containing drinks, natural fruit juices, alcoholic or vitality drink, any supplying form of vitamin $\mathrm{C}$, ibuprofen and a few verbal cleanliness items, counting a few mouth washes ${ }^{(5)}$.

Oral medicine is viewed as one of the external causes of dental erosion since some chronic diseases' medicines having high acidity ${ }^{(6)}$. Properly, numerous cases of tooth chemical wear have been reported as a result to oral administration of specific medications ${ }^{(7)}$.

Teeth are continuously subjected to cycles of de-mineralization and re-mineralization throughout the life, but these cycles could be interrupted by excessive uptake of acidic drinks which eventually leads to disintegration of inorganic component of the teeth ${ }^{\left({ }^{8}\right)}$. This chemical dissolution, in case not conveniently treated, may cause tooth sensitivity, decrease the tooth vertical dimensions, pulpal exposure and inflammation ${ }^{(9,10)}$.

Some acids are contained in drug formulations as a buffering agent to save compound dependability, control constitution and as a flavoring agent to increase the agreeability to the kids. Some oral prescriptions contained citric acid which has efficient erosive effect since it has liability to bond with the calcium $(\mathrm{Ca})$ in hydroxy-apatite that accelerate the hydroxy-apatite crystals disintegration rate ${ }^{(11)}$. plus, faster enamel erosion can be formed when these prescriptions are used for chronic diseases since it has at least twice daily frequent regular uptake ${ }^{(12)}$.

Antihistaminic drugs are endorsed by pediatricians for quieting the side effects of occasional sensitivities, for example, runny nose; sniffling; irritated eye's secretions or nose tingling. Especially, Claritin syrup which is one of the anti-histaminic drugs which is comprehensively recommended by most pediatricians; therefore, it is exhausted by a huge prominence of children ${ }^{(13)}$.
Claritin syrup has a trait of giving erosive potential because of its high acidity, since it contained citric acid, no phosphate or fluoride, and negligible amount of $\mathrm{Ca}$ in the chemical composition ${ }^{(14)}$. Subsequently, many reports revealed the erosive effect of Claritin syrup in dental field ${ }^{(15-19)}$.

Demineralization can be re-established through utilizing calcium-phosphate compound. Advanced dental compounds containing $\mathrm{Na} F$ or tri $\mathrm{CaPo}_{4}$ have presently been one of the foremost premier viable sources of in-organic elements essentially needed to re-mineralize enamel ${ }^{(20)}$. One of the milk derivative products is Phospho-peptide-amorphous-calciumphosphate (CPP-ACP) which has seemed to be encouraging results both in-vivo and in-vitro in improving the enamel remineralization and treating the enamel erosion therefore, it has been effectively included in some oral and dental compounds ${ }^{(21)}$. As well, the different applications of chicken eggshell powder (CESP) were considered ${ }^{(22)}$.

Chicken egg-shell is an effective origin of calcium, contains about $40 \%$ of basic calcium. It isn't just enhancing the in-vitro differentiation of chondrocyte yet additionally improving the thickness of bone mineral in female rat ${ }^{(23)}$. Moreover, CESP have improved the density of bone mineral and decreased the joint pain in post-menopausal ladies suffering from osteoporosis ${ }^{(24)}$.

Numerous studies tried to evaluate the effects of various re-mineralizing agents on early enamel caries stage, however shortage of data still present about the application of CESP and its efficiency on the treatment of eroded surface of enamel caused by pediatric medications ${ }^{(25,26)}$.

Withdrawal of enamel hardness is the initial sign of dental erosion. Here, a platform of the hydroxyapatite crystal still present. At that stage, the re-mineralization process by calcium, phosphorus and fluorides could be done efficiently. On the contrary, when the scaffold is completely lost, remineralizing agents are not significantly effective. 
In the beginning of dental erosion there is a reduction in the surface hardness of the enamel however, it could be increased after re-mineralization procedures ${ }^{(27)}$.

Degradation of hydroxyapatite crystals of enamel leading to mineral loss from the sub-surface layer, creating gaps among the enamel rods, and resulting in roughened enamel surface ${ }^{(28)}$ The roughened surfaces cause plaque retention, which increases the demineralization rate and, possibly resulted in many oral diseases ${ }^{(29)}$. Therefore, surveying surface roughness and surface hardness of enamel is a valuable tool to confirm the efficacy of different remineralizing agents.

The objective of our in-vitro analysis is to investigate the re-mineralization efficiency of chicken-eggshell powder slurry on artificially induced erosive lesion in primary teeth measured by surface roughness and microhardness

\section{Production and of Chicken Eggshell Powder (CESP)}

Calcination was the process used for formation of CESP through the methodology described by World-Property-Intellectual-Organization (WO/ 105912/ 2004) (31) to get an unadulterated sterile powder with extended alkalinity. Basically (CESP) have $94-97 \%$ calcium carbonate that turned into basic calcium oxide by calcination process, which is the cause of increased alkalinity (32). Forty chicken-eggs from a local hatchery (Tanta) have been obtained and their contents were removed, and the eggshells have been cleaned in distilled water. The eggshells then preserved in a hot water-bath at $100^{\circ} \mathrm{c}$ for 10 minutes to facilitate the membrane removal. Then it has been crushed by mortar and pestle. The resulted crushed powder was heat treated at $1200^{\circ} \mathrm{C}$ in a muffle furnace (Henan Sante Furnace Technology Co., Ltd, China) for 1 hour and finally powdered ${ }^{(33,34)}$. To form the CESP slurry, $1 \mathrm{gm}$ of powder was mixed with $2 \mathrm{ml}$ artificial saliva ${ }^{(35)}$.

\section{MATERIALS AND METHODS:}

\section{Materials}

The materials used in this study are described in table (1)

TABLE (1): Materials used in the present study

\begin{tabular}{|c|c|}
\hline Material & Description \\
\hline Claritin syrup (Schering-Plough) & $\begin{array}{l}\text { an anti-histaminic syrup which contains citric acid, loratadine } 1 \mathrm{mg} / \mathrm{ml} \text {, } \\
\text { glycerin, flavoring agent, sodium benzoate, sugar and glycol propylene, Inactive } \\
\text { components (corn starch, lactose monohydrate, magnesium stearate) and water. } \\
\text { Bayer- HealthCare LLC. }\end{array}$ \\
\hline Chicken-eggshell powder (CESP) & $\begin{array}{l}\text { It was prepared by calcination process at Physics Department, Faculty of } \\
\text { Science, Tanta University }\end{array}$ \\
\hline Artificial saliva & $\begin{array}{l}\text { It is composed of }\left(0.843 \mathrm{~g} \mathrm{NaCl}, 1.2 \mathrm{~g} \mathrm{KCl}, 0.051 \mathrm{~g} \mathrm{MgCl}_{2}, 20 \mathrm{ml} \text { of } 1 \% \text { solution }\right. \\
\text { of tri-calcium phosphate and carboxy methylcellulose, } 0.05 \mathrm{M} \text { of } \mathrm{NaOH} \text { to } \\
\text { adjust the pH to } 6.8) \text { mixed with } 500 \mathrm{ml} \text { distilled water }\end{array}$ \\
\hline
\end{tabular}




\section{Characterization of the prepared CESP:}

- The chemical composition of CESP was analyzed using FTIR FT-IR spectroscopy (Perkin-Elmer-1430 Ratio Recording Infrared Spectrophotometer, USA) Then the morphology and the particle size of the powder was analyzed by Scanning Electron Microscope (SEM) (JEOL, JSM 5410, Japan.)

- To prepare CESP slurry, one gram of the prepared chicken eggshell powder was mixed with $2 \mathrm{ml}$ of artificial saliva, and then the tooth was rubbed by finger with freshly mixed slurry for 3 minutes. ${ }^{(35)}$

\section{Sample Preparation}

Totally 20 freshly extracted sound deciduous anterior teeth have been collected from the pedodontics clinic, faculty of dentistry, Tanta University. The objectives of the present investigation have been explained to the children's parents and informed consents were obtained to use their extracted teeth on the research according to the guidelines on human research established by ethics committee panel of faculty of Dentistry-Tanta University.

The collected teeth were cleaned, disinfected by soaking in $5 \%$ solution of sodium hypo-chloride for $60 \mathrm{~min}$., and carefully examined. Any defected or cracked teeth were excluded. Then, the selected sound teeth specimens were stored in normal saline till used ${ }^{(36)}$.

Roots of the selected teeth had been cut at the enamel-cementum junction using (Isomet 4000 microsaws, Buehler, USA). The crown specimens were sectioned through the bucco-lingual axis into equal two halves to utilize one of them as a control, and the others as a study. The tooth segment was embedded in Tef1on mold (10mm x $8 \mathrm{~mm}$ x $2 \mathrm{~mm})$ with a composite resin so that their labial surface directed upwards. Silicon-carbide papers (grades 600-1200) under running stream of water, were used to grind and polish the labia1 surfaces of the specimens to produce a highly flat surface ${ }^{(37)}$.

\section{Grouping}

Group I (Control Group): one half of 20 tooth specimens were exposed to erosive syrup and left with no treatment.

Group II (Study Group): the other one half of 20 teeth specimens were exposed to the erosive syrup then re-mineralized with CESP slurry treatment.

The acidity of the anti-histaminic syrup was detected before using it as a de-mineralizing syrup by $\mathrm{pH}$-electrode meter (MP 23o pH-meter, Mettler Toledo) at the Chemistry lab-Faculty of Pharmacy, Tanta University and it was found that its $\mathrm{pH}$ equals 3.4.

\section{Experimenta1 methodo1ogy:}

\section{Group I (control group)}

The 20 control group specimens were scheduled and examined for surface roughness and microhardness (baseline evaluation).

Erosive lesion formation (36,37,38): All specimens had been soaked in Claritin syrup for $1 / 2$ hour twice daily for 12 days in a shut compartment. The specimens were washed in distilled water for 5 seconds between the erosive cycles and stored in artificia1 sa1iva til1 be used again. Artificial sa1iva was daily refreshed as well as Claritin syrup before each cycle ${ }^{(8)}$. Group I specimens were not subjected to any treatment. Following 12 days of erosion cycles, they have been examined for surface roughness and microhardness as a (final evaluation).

\section{Group II (study group)}

The 20 study group specimens were scheduled, numbered and examined for surface roughness and micro-hardness as a (baseline evaluation) prior to application of de-mineralizing agent. The previous technique used with group I was followed.

Remineralization (39-41): The samples were rubbed by finger with freshly mixed CESP slurry for 3 minutes twice daily. Then washed with distilled 
water for 5 seconds to eliminate the excess material then kept in artificial saliva at $37{ }^{\circ} \mathrm{C}$ for the rest of the day. This cycle was repeated for 10 days. After this time, all tooth specimens have been analyzed for roughness and micro-hardness (re-mineralization evaluation).

\section{Surface roughness evaluation ${ }^{(42)}$ :}

For the determination of surface roughness values, Surface Profilometer (Posi-tecter, SPG, Deflesko Co., USA) was used. The gauge is turned on and its probe is carefully positioned to the examined surface. For each specimen, five readings have been recorded and the mean value for each specimen was determined.

\section{Surface microhardness evaluation ${ }^{(43)}$}

After completing the surface roughness testing, the same specimens were used for determination of hardness values. Measuring of microhardness have been done using a microhardness indenter (ZwicRoell, west Midlands, England) as an initial assessment then following the estimated 12 days' time period of erosive cycles for the group I (control group) specimens. For group II specimens, micro-hardness measuring had been performed as an initial assessment and following the CESP re-mineralization treatment by Vickers Microhardness tester. Force of $100 \mathrm{gm}$ have been loaded to the specimen's surface with a dwell time of 15 sec. Five indentations have been equally positioned over 1-mm diameter circle at the center of the specimens and five readings were recorded for the top surfaces of each specimen. The diagonal length of the indentations was detected, then Vickers micro-hardness number was calculated as follow:

VHN=1.854 P/d2 where:

VHN: is Vickers hardness number in $\mathrm{Kg} / \mathrm{mm}^{2}$,

$\mathrm{P}$ : is the force in $\mathrm{Kg}$,

$\mathrm{d}$ : is the length of the diagonals in $\mathrm{mm}$,

\section{Statistical Analysis}

The collected data organized, tabulated and statistically analyzed using SPSS software statistical computer package version 20. The mean and standard deviation were calculated with significance level $5 \%$. and t-test was performed to compare between each before and after interventions.

\section{RESULTS}

\section{Characterization of the prepared CESP}

Figure (1) showed FTIR spectrum of calcined CESP. The peak at $3431 \mathrm{~cm}^{-1}$ is attributed to $\mathrm{OH}$ in calcium hydroxide that was established during absorption of $\mathrm{H}_{2} \mathrm{O}$ by calcium oxide. The bands at 875.08 and $1428.55 \mathrm{~cm}^{-1}$ were related with the vibrations of the $\left(\mathrm{CO}_{3}\right)$ groups. FTIR spectra of the chicken eggshell samples calcined to $1200^{\circ} \mathrm{C}$ for $1 \mathrm{~h}$ revealed characteristic bands of the $\mathrm{CaCO}_{3}$ structure at $712,876,1423,1798,2515$, and $3435 \mathrm{~cm}^{-1}$.

\section{Scanning electron microscope images (SEM):} the micrograph of calcined eggshell powder is shown in Figure 2. The morphology of calcined eggshell powder nearly round shaped particles was found for all the samples, with agglomeration of particles giving the shape of cloud. The powder particle size ranged from $75 \mathrm{~nm}$. to $210 \mathrm{~nm}$.

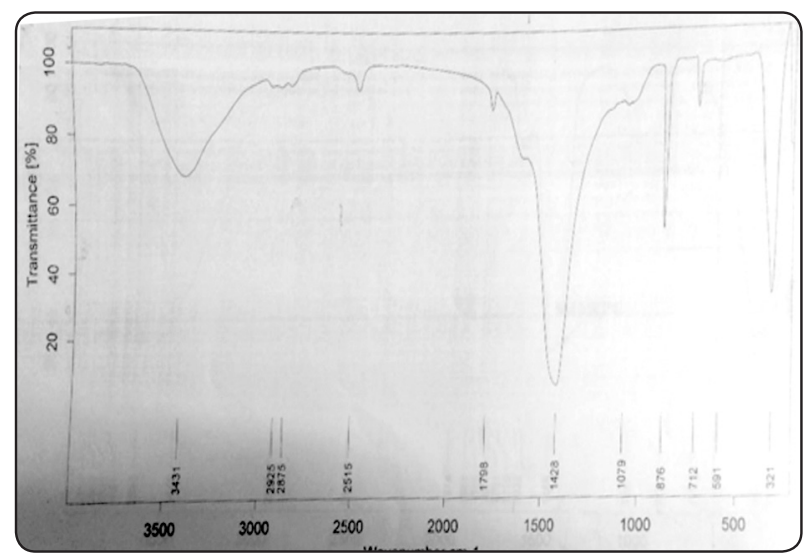

Fig. (1) FTIR spectrum of calcined chicken eggshell powder (CESP) 


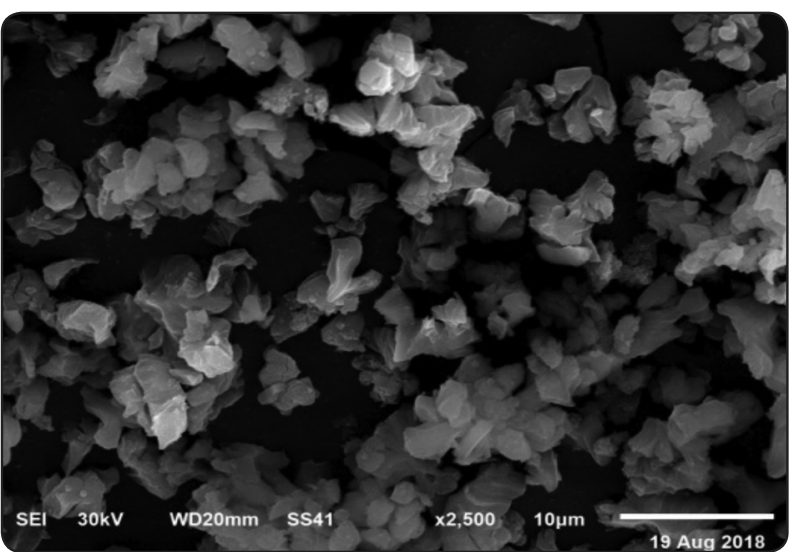

Fig. (2) SEM micrographs of calcined chicken eggshell powder (CESP)

\section{Surface roughness}

Referring to table (2), it was found that, roughness of enamel surface was increased following 12 days application of Claritin syrup. There was significantly different change $(\mathrm{p}<0.001)$ after erosion with the antihistaminic syrup. However, after treatment with CESP slurry, there was a statistically significant decrease in enamel roughness value ( $\mathrm{P}$ value was $<0.001)$.

\section{Surface microhardness}

Table (2) showed that, microhardness values were significantly decreased $(\mathrm{P}<0.001)$ following erosive cycles with Claritin syrup. On the other hand, after treatment with CESP syrup, microhardness values were significantly increased as $\mathrm{P}<0.001$.

TABLE (2): Mean \pm SD of surface roughness and microhardness of the tested groups

\begin{tabular}{|c|c|c|c|c|c|}
\hline \multirow{6}{*}{$\begin{array}{l}\text { Surface } \\
\text { roughness }\end{array}$} & \multicolumn{5}{|c|}{ 1-Surface roughness at initial and following erosion with the Claritin syrup } \\
\hline & & Base line & following erosion & $\mathbf{T}$ & P value \\
\hline & Mean \pm SD & $1.57 \pm .085$ & $2.56 \pm 0.0872$ & 2.224 & $<0.001 *$ \\
\hline & \multicolumn{5}{|c|}{ 2- Surface roughness after treatment with CESP slurry following erosion by Claritin syrup } \\
\hline & & $\begin{array}{l}\text { following erosion } \\
\text { (contro1 group) }\end{array}$ & $\begin{array}{c}\text { following re-mineralization } \\
\text { (study group) }\end{array}$ & & \\
\hline & Mean \pm SD & $2.56 \pm 0.0872$ & $1.756 \pm 0.0587$ & 18.552 & $<0.001 *$ \\
\hline \multirow{6}{*}{$\begin{array}{c}\text { Surface } \\
\text { microhardness }\end{array}$} & \multicolumn{5}{|c|}{ 1-Surface microhardness at initial and following erosion with Claritin syrup } \\
\hline & & Base line & following erosion & & \\
\hline & Mean \pm SD & $171 \pm .5 .33$ & $81 \pm 3.056$ & 16.552 & $<0.001^{*}$ \\
\hline & \multicolumn{5}{|c|}{ 2- Surface microhardness following treatment with CESP slurry after erosion by Claritin syrup } \\
\hline & & $\begin{array}{l}\text { following erosion } \\
\text { (control group) }\end{array}$ & $\begin{array}{l}\text { following re-mineralization } \\
\text { (study group) }\end{array}$ & & \\
\hline & Mean \pm SD & $81 \pm 3.056$ & $140 \pm 6.05$ & 3.135 & $<0.001 *$ \\
\hline
\end{tabular}




\section{DISCUSSION}

Dental erosion is characterized by loss of the tooth surface either by extrinsic or intrinsic acidic agent ${ }^{(44)}$. This will be leading to a progressive softening of the superficial and sub-surface layer of enamel ${ }^{(45)}$.

Some pediatric syrup medications have a certain acidic component that support the chemical stability, tonicity or improve their flavor, which have a role in increasing their erosive potentiality. Several types of these pediatric medicines are usually used daily in long term treatments of children ${ }^{(46)}$. As well, these children could be subjected to other sources of erosion, that will expose the tooth structure to a magnifying amount of acids ${ }^{(17)}$. Accordingly, the aim of the present investigation was to evaluate the remineralization efficiency of chicken eggshell powder (CESP) slurry on artificially induced erosion in primary teeth measured by surface roughness and microhardness.

Spectroscopic imaging is that the method of choice for monitoring and analysis of the chemical composition of the CESP because of the chemical specificity of this imaging approach ${ }^{(47)}$. Fourier Transform Infrared (FTIR) spectroscopy had been proven to be an efficiently tool in material characterization. The chemically specific information contained within the unique "fingerprint" region of the IR spectrum allows one to tell apart different materials within a mixture ${ }^{(48-50)}$.

The medical syrup selected for the present study (Claritin) have some characteristics as high acidity as it contains citric acid - low phosphate and fluoride - and trace of calcium in the chemical composition which potentiate its erosive efficiency (15). This was agreed with the detected acidic value $=4.2$. Furthermore, Claritin syrup is the most used antihistaminic syrup in pediatric health ${ }^{(13,15,16,17,19)}$.

Generally, erosion studies are conducted extra orally, to standardize many parameters ${ }^{(51)}$
Basically, there is a difference in the structure between the primary and permanent teeth. Deciduous tooth has lower minerals than permanent one therefore, progression of erosion could be faster in deciduous tooth, wherefore, it was decided to be used ${ }^{(52)}$

Saliva is playing a vital efficient role in resisting enamel erosion. This can be since; it contains a ranged salt of carbonate that can help in the neutralization of acids ${ }^{(53)}$. Therefore, within the current study, artificially prepared saliva has been chosen as a storage media among the erosive cycles.

Loss of hardened enamel by erosion is efficiently evaluated by detecting its roughness and microhardness. These two methods can accurately detect the harmful effect formed by erosive syrup ${ }^{(11,54)}$. Therefore, these two surface evaluations were selected in the present study.

Multiple exposure of erosive medication was found to be recommended than single exposure $(11,15,16)$ as changes will be clearly noticed following several exposures ${ }^{(55)}$ therefore, it was selected to be used.

The erosion protocol of enamel has been performed by immersing all the teeth specimens in Claritin syrup for $1 / 2$ hour twice daily for 12 days. The regime has been chosen to resemble the longterm use (multiple exposure) of anti-histaminic syrup as recommended by valenoti et al ${ }^{(16)}$.

Surface roughness and microhardness results revealed that 12 twice daily acid exposure to Claritin syrup was efficient to form enamel demineralization that shown by marked increase in the roughness values and diminished micro-hardness values of the teeth specimens. This was agreed with results of Costa et $\mathrm{al}^{(15)}$, Valinoti et $\mathrm{al}^{(16)}$, Gaber et $\mathrm{al}^{(36)}$ and Feroz et $\mathrm{al}^{(37)}$

Recently, there was a marked highlighting on the advancement of non-toxic re-mineralizing compounds ${ }^{(56)}$. Actually, CESP has a protective effect as it can act as a store of ions that prevents 
enamel de-mineralization and enhances the remineralization process. Calcium and phosphate ions present in saliva act as building blocks for remineralization process and preventing the erosive de-mineralization. Also, it was found that CESP has an efficient role in the re-mineralization of the early enamel carious lesion ${ }^{(31)}$

In the present study, CESP slurry was topically applied on the demineralized tooth surface of group II twice daily for 10 days the regime that was prescribed by Darshan et al ${ }^{(57)}$ and Talaat et $\mathrm{al}^{(40)}$ whose regimes had showen a significant remineralizing effect in-vitro.

Surface roughness and micro-hardness results revealed that, topical treatment with CESP slurry significantly reduced the mean surface roughness and enhanced the micro-hardness of the de-mineralized group II tooth specimens that indicated the process of re-mineralization. The present finding is supported by those of Feroz and Moeen (25) and Feroz et $\mathrm{al}^{(26)}$ who recorded enhancement on the hardness and decrease on the surface roughness following the use of CESP. Thus, it was enhancing the in-vitro re-mineralization of eroded enamel.

\section{CONCLUSIONS}

Within the limitation of the present study, the conclusions are:

1. Chicken eggshell powder slurry is an effective re-mineralized treatment against dental erosion initiated by antihistaminic syrup.

2. Claritin antihistaminic syrup had induced an extreme erosion on deciduous tooth enamel. In this way, it is very essential to the clinicians specially to be acquainted with the potential of erosion for the most used syrups.

3. Roughness and micro-hardness testing are precise and valuable strategy to evaluate the demineralization and re-mineralization of enamel surface in-vitro.

\section{REFERRENCES}

1. Poggio C LM, Dagna A, Chiesa M, Bianchi S. Protective effect on enamel demineralization of a CPP-ACP paste: An AFM invitro study. J Dent 2009; 37:949-954.

2. Harley K. Tooth wear in the child and the youth. Br Dent J. 1999; 186: 492-6.

3. Wiegand A \& Attin T. Occupational dental erosion from exposure to acids: a review. Occup Med (Lond). 2007; 57:169-76

4. Lazarchik DA \& Filler SJ. Effects of gastroesophageal reflux on the oral cavity. The American journal of medicine. 1997; 103(5): 107-13.

5. Ren YF. Dental Erosion: Etiology, Diagnosis and Prevention, a Peer Review Publication, 2013. Pages 87-95.

6. Taji S \& Seow WK. A literature review of dental erosion in children. Aust Dent J. 2010; 55: 358-67.

7. Jaeggi TLA. Prevalence, Incidence and distribution of erosion. Monogr Oral Sci 20:44-65. 2006.

8. Babu KL, Rai K, Hedge AM. Pediatric liquid medicaments-do they erode the teeth surface? An in vitro study: part I. J Clin Pediatr Dent. 2008; 32: 189-94.

9. Moss SJ. Dental erosion. Int Dent J. 1998; 48:529-39.

10. Shaw L \& Smith A. Paediatric Dentistry: Dental erosionthe problem and some practical solutions. British dental journal. 1999; 186(3): 115-8.

11. Scatena C, Galafassi D, Gomes-Silva JM, Borsatto MC, Serra MC. In vitro erosive effect of pediatric medicines on deciduous tooth enamel. Braz Dent J. 2014; 25: 22-7.

12. Van Rijkom HM, Truin GJ, Frencken JE, König KG, van 't Hof MA, Bronkhorst EM, et al. Prevalence, distribution and background variables of smooth-bordered tooth wear in teenagers in The Hague, the Netherlands. Caries Res. 2002; 36: 147-54.

13. Del Cuvillo A, Sastre J, Montoro J, Jáuregui I, Ferrer M, Dávila I, et al. Use of antihistamines in pediatrics. J Investig Allergol Clin Immunol. 2007; 17: 28-40.

14. Viviane P, Lucianne M, Thiago IV, Monique C, Michele $\mathrm{V}$, Lucio MC. Effect of Dilution on the PH and Titratable Acidity of Pediatric Syrup Medicines.J bacterial parasitol. 2013; 2: 595-62.

15. Costa CC, Almeida IC, Costa Filho LC. Erosive effect of an antihistamine-containing syrup on primary enamel and 
its reduction by fluoride dentifrice. Int J Paediatr Dent. 2006; 16: 174-80.

16. Valinoti AC, Pierro VS, Da Silva EM, Maia LC. In vitro alterations in dental enamel exposed to acidic medicines. Int J Paediatr Dent. 2011; 21: 141-50.

17. Xavier AF, Moura EF, Azevedo WF, Vieira FF, Abreu MH, Cavalcanti AL. Erosive and cariogenicity potential of pediatric drugs: study of physicochemical parameters. BMC Oral Health. 2013; 10: 13-71.

18. Xavier AF, Abreu MHNG, Melo JBCA, Anselmo GCS, Cavalcanti AL. Changes in microhardness and morphology of the adamantine structure as a function of the exposure time to different drugs. Braz Res Pediatr Dent Integrated Clinic. 2015; 15: 279-89.

19. Alexandria AK, Meckelburg NA, Puetter UT, Salles JT, Souza IP, Maia LC. Do pediatric medicines induce topographic changes in dental enamel? Braz Oral Res. 2016; 30:159-87.

20. Kato MT LM, Sales-Pares SH, Buzalaf MA. "Preventive effect of commercial desensitizing toothpastes on bovine enamel erosion in vitro". Caries Res. 2010; 44: 85-9.

21. Reynolds EC. "Remineralization of enamel subsurface lesions by casein phosphopeptide -stabilization calcium phosphate solutions", J Dent Res. 1997; 79(9): 1587-95.

22. Schaafsma AVDJ, Muskiet FA, Hofstede GJ, Pakan I, van der Veer E. "Positive effects of a chicken eggshell powder -enriched vitamin-mineral supplement on femoral neck bone mineral densityin healthy late post-menopausal Dutch women". Br J Nutr. 2002; 87(3): 267-75.

23. Park JW BS, Suh JY, Lee DH, Kim SH, Kim H, et al. "Evaluation of bone healing with eggshell-derived bone graft substitutes in rat calvaria: a pliot study". J Biomed Mater Res A. 2008; 87(1): 203-14.

24. Rovensky J SM, Masaryk P, Svik K, Istok R. "Eggshell calcium in the prevention and treatment of osteoprosis". Int J Clin Pharmacol Res. 2003; 23(2-3): 83-92.

25. Feroz S. \& Moeen F. Protective effect of two different remineralizing agents on artificially induced dental erosion in primary and permanent teeth: an in-vitro analysis. Pakistan Oral \& Dental Journal . 2017; 37(4): 657-666.

26. Feroz S., Moeen F, Haq SN. Protective Effect of Chicken Egg Shell Powder Solution (CESP) on Artificially Induced Dental Erosion: An in Vitro Atomic Force Microscope Study. International J.Dent. Sci.and Res. 2017; 5(3):49-55.
27. Katakam D,. Priyadarshini SH, Raghu R, Shetty A, Premlatadevi T, Cherukuri S. An In Vitro Comparative Evaluation Of Enamel Microhardness In Soft Drinks, Cpp-Acp, Amine Fluoride And Sodium Fluoride With Functionalised Tricalcium Phosphate. J. Evolution Med. Dent. Sci. 2017; 6(4): 273-277.

28. Fava M, Frascino A V, Balducci I, Ramos C J. Comparative analysis of different prophylactic methods for roughness of primary tooth enamel. Braz Dent Sci. 2018 ;21(3): 335-341

29. Azrak B, Callaway A, Kurth P, Willershausen B. Influence of Bleaching Agents on Surface Roughness of Sound or Eroded Dental Enamel Specimens J Esthet Restor Dent. 2010; 22: 391-401.

30. Claritin Information. 2016. Available at: http://www.rxlist. com/claritin-drug.htm

31. Mony B, Ebenezar R, Chani MF, Narayanan A, Anand S, Mohan A.G.. Effect of Chicken Egg Shell Powder Solution on Early Enamel Carious Lesions: An Invitro Preliminary Study. Journal of Clinical and Diagnostic Research. 2015; 9(3): ZC30-ZC32.

32. Zaman T, Mostari M. S,. Al Mahmood M. A,. Rahman M. S.. Evolution and characterization of eggshell as a potential candidate of raw material. Cerâmica. 2018; 64 :236-241

33. Buasri, Achanai, Chaiyut, Nattawut, Loryuenyong, Vorrada, Wongweang, Chaiwat, Khamsrisuk, Saranpong,. Application of eggshell wastes as a heterogeneous catalyst for biodiesel production. Sustain. Energy. 2013; 1, 7-13.

34. Fernández-Ferrer L, Vicente-Ruíz M, García-Sanz V, Montiel J M ,Paredes-Gallardo V, Almerich-Silla J M, Bellot-Arcís C, Enamel remineralization therapies for treating postorthodontic white-spot lesions. 2018; 149 (9), 778-786.

35. Haghgoo R, Mehran M, Ahmadvand M, Ahmadvand M.J. Remineralization Effect of Eggshell versus Nanohydroxyapatite on Caries-like Lesions in Permanent Teeth (In Vitro). J Int Oral Health. 2016; 8(4):435-439 .

36. Gaber A M, Dowidar K M, Talaat D M. The effect of CCP-ACP on the surface microhardness of primary tooth enamel eroded by antihistamine syrup (in vitro study). Alex.Dent. J.2016;41: 86-91

37. Feroz S, Aamir S, Nawabi S. Susceptibility of Human Deciduous Enamel to Erosive Wear after Exposure to Commonly Prescribed Oral Pediatric Liquid Medicaments: 
An AFM Based in vitro Analysis. Int J Dent Sci and Res, 2018; 6(5): 138-142

38. Arora , R.; Mukherjee, U.; Arora , V. Erosive potential of sugar free and sugar containing pediatric medicines given regularly and long term to children . Indian J. Pediatr. 2012, 79, 759-763.

39. Cem G, Ebru C, Seval Ö. Remineralizing effect of different topical agents on occlusal surfaces with or without caries: an in vitro evaluation study using electrical resistance measurements. Clin Dent and Res. 2012; 36: 4-9.

40. Talaat DM \& Mahmoud A. Acid Resistance of Enamel Subsurface Lesions Treated with Casein Phosphopeptide Amorphous Calcium Phosphate Fluoride. J Dent Child. 2015; 82: 70-5.

41. Lata S, Varghese NO, Varughese J M. Remineralization potential of fluoride and amorphous calcium phosphate-casein phospho peptide on enamel lesions: An in vitro comparative evaluation. J Conserv Dent. 2010; 13(1):42-46.

42. El-safty SM \& Abdel Karim U M. Surface Roughness and Hardness of Dental Resin-Composites Intended for Bulkfill Placement. 2018; 64, 1241:1249.

43. Badr SB \& Ibrahim MA. Protective effect of three different fluoride pretreatments on artificially induced dental erosion in primary and permanent teeth. Am J Sci. 2010; 6:424-51.

44. Lussi A \& Carvalho TS. Erosive tooth wear: a multifactorial condition of growing concern and increasing knowledge. Monogr Oral Sci. 2014;25: 1-15.

45. Lussi A \& Carvalho TS. The future of fluorides and other protective agents in erosion prevention. Caries Res 2015;49Suppl 1:18-29.

46. Maguire A, Baqir W, Nunn JH. Are sugars-free medicines more erosive than sugars-containing medicines? An in vitro study of paediatric medicines with prolonged oral clearance used regularly and long-term by children. Int J Paediatr Dent 2007;17:231-238.

47. Schaafsma A D J, Muskiet FA, Hofstede GJ, Pakan I, van der Veer E.: Positive effects of a chicken eggshell powder -enriched vitamin-mineral supplement on femoral neck bone mineral density in healthy late post-menopausal Dutch women. Br J Nutr, 2002; 87(3): 267-75.

48. Wetzel D. and Reffner J.: Infrared spectroscopy goes microscopic. Chem. Ind., 2000;34:308-13.

49. Pradhan A K and Sahoo P K: Synthesis and study of thermal, mechanical and biodegradation properties of chitosan-g-PMMA with chicken egg shell (nano- $\mathrm{CaO}$ ) as a novel bio-filler. Materials Science and Engineering C 80 2017; 149-155.

50. Al Mijan A, Dong-Hwi Kim \& Hae-Soo Kwak. Physicochemical properties of nanopowdered eggshell. Int. J. of Food Science and Technology 2014; 49, 1751-1757

51. West NX, Hughes JA, Addy M. Erosion of dentine and enamel in vitro by dietary acids: the effect of temperature, acid character, concentration and exposure time. J Oral Rehabil. 2000; 27: 875-80.

52. Hunter ML, West NX, Hughes JA, Newcombe RG, Addy M. Relative susceptibility of deciduous and permanent dental hard tissues to erosion by a low $\mathrm{pH}$ fruit drink in vitro. J Dent. 2000; 28: 265-70.

53. Hara AT, Ando M, González-Cabezas C, Cury JA, Serra MC, Zero DT. Protective effect of the dental pellicle against erosive challenges in situ. J Dent Res. 2006; 85: 612-6.

54. Tantbirojn D, Huang A, Ericson MD, Poolthong S. Change in surface hardness and roughness of enamel by a cola drink and a CPP-ACP paste. J Dent. 2008; 36:74-79.

55. Barbour ME, Lussi A, Shellis RP. Screening and prediction of erosive potential. Caries Res. 2011; 45: 24-32.

56. Bhagavatula P, Levy SM, Broffitt B, Weber-Gasparoni K, Warren JJ. Timing of fluoride intake and dental fluorosis on late-erupting permanent teeth. Community Dent Oral Epidemiol. 2016; 44: 32-45.

57. Darshan HE \& Shashikiran ND. The effect of McInnes solution on enamel and the effect of Tooth mousse on bleached enamel. J Conserv Dent. 2008; 11:86-91. 